\title{
Constitutionality of State Control Meaning on Mineral and Coal Mining Field
}

\author{
Muchamad Taufiq ${ }^{1} \quad$ Sudarsono $^{2} \quad$ M. Khoidin ${ }^{3} \quad$ Aries Harianto $^{4}$ \\ 1.Doctorate Students at Faculty of Law, University of Jember \\ 2.Professor and Lecturer at Faculty of Law University of Barwijaya \\ 3.Professor and Lecturer at Faculty of Law University of Jember \\ 4.Doctor and Lecturer at the faculty of Law, University of Jember
}

\begin{abstract}
The constitutionality of state control meaning is the regulatory concept contained in Article 33 of the 1945 Constitution of the Republic of Indonesia. In this case, the context of control concerns on mineral and coal mining which will be further regulated by the laws and regulations. Act No. 4 of 2009 on Mineral and Coal Mining in Article 92 gives authority in the form of rights for the holders of Mining License (hereinafter referred to as ML) and Special Mining License (hereinafter referred to as SML) to own minerals, including associated minerals, or coal that has been produced if they have fulfilled exploration fees or production fees except for radioactive minerals. Such an arrangement shows that the authority of the ML/SML holder is a form of freedom to trade these mining materials so that it has the potential to obscure the constitutional rights of the state to control, and causes the position of the state is subordinated to business actors. Through normative juridical research types with various approaches, this research was conducted in dealing with legal issues, especially on examining the philosophical meaning of state control and the consistency of the constitutionality of the rights of ML/SML holders to the 1945 Constitution of the Republic of Indonesia. The result has disclosed that the actual meaning of the right of state control is the embodiment of positioning the people as subjects to gain prosperity. Meanwhile, the regulation giving the ML/SML holder the authority to legally own minerals and coal is contrary to the constitution.
\end{abstract}

Keywords: constitutionality, state control, authority, sub-ordination

DOI: $10.7176 / \mathrm{JLPG} / 111-02$

Publication date:July $31^{\text {st }} 2021$

\section{Introduction}

The Unitary State of the Republic of Indonesia through the 1945 Constitution of the Republic of Indonesia as the constitutional basis has explained in Article 33 paragraph (3) that the earth and water and the natural resources contained therein are controlled by the State and used for the greatest prosperity of the people. Collectively, the people are constructed by the 1945 Constitution of the Republic of Indonesia which mandates the state to carry out policies (beleid) and arrangement (bestuursdaad), regulation (regelendaad), management (beheersdaad) and supervision (toezichthoudensdaad) for the purpose of the greatest prosperity of the people. The issue of mineral and coal mining business activities will not be separated from the concept of mineral and coal mining authority. Both are complete and absolute unity that cannot be separated from one another. This whole and unanimous unity is clearly seen from the provisions in Article 33 paragraph (3) of the 1945 Constitution of the Republic of Indonesia in the phrase of "state control" and "for the greatest prosperity of the people."

These two phrases are sacred phrases that must be the soul of the implementation of mineral and coal mining in Indonesia. The phrase "state control" is the soul of "having authority" over mineral and coal mining, while the phrase "for the greatest prosperity of the people" is the soul of the purpose of organizing mineral and coal mining of a business. Thus, the essence of Article 33 paragraph (3) of the 1945 Constitution of the Republic of Indonesia is the absolute and unanimous soul in the implementation of mineral and coal mining organically carried out by the legislation under the 1945 Constitution of the Republic of Indonesia. According to the theory, there are several definitions of the welfare state that can be defined as a social welfare system giving a large role to the state or government (to allocate some public funds to ensure the fulfillment of the basic needs of its citizens). Thus, it can be concluded that the welfare state protects the community, especially the weak groups such as the poor, disabled, unemployed etc. On the other hand, it is important to put an equal position and situation among each individual in society, thus one party and another can make an equal agreement. Everyone is blurred about the developing concept or knowledge of justice. Thus, society shall be educated to obtain the principle of fair equality.

The provision on Article 92 of the Act on Mineral and Coal Mining stated "holders of ML and SML shall be entitled to own minerals, including associated minerals, or coal that have been produced after they have paid exploration or production royalty, except for radioactive associated minerals." This provision guarantees freedom for ML/SML holders, after paying the production fee to own and trade the mineral products they have produced. Legally, by paying royalties, it means there has been a transfer of ownership from the state to the 
ML/SML holder, so that the ML/SML holder has the right to trade it, including exporting it.

Based on the above description, the provisions of Mineral and Coal Mining Law indicate disharmony as a legal problem with the substance of the 1945 Constitution of the Republic of Indonesia Article 33 paragraph (3), which immediately brings new legal problems. Thus, the author presented these legal issues in the form of a problem formulation formulated in the following questions: (1). What is the philosophical meaning of State Control over Mineral and Coal Mining? (2). Is the right of the holder of a Mining License and a Special Mining License to own minerals including associated minerals, or coal produced if they have paid the exploration or production royalty as stipulated in Article 92 of Act Number 4 of 2009 contrary to the provision of Article 33 paragraph (3) of the 1945 Constitution of the Republic of Indonesia?

\section{Method}

This research aims at revealing the truth in a systematic, methodological and consistent manner, including legal research. Legal research is different from social research because law is not a social science category. Law is $s u i$ generis (Philipus M.Hadjon, Tatik Sri Djatmiati, 2005: 1), meaning that law is a separate kind of science. Characteristics sui generis shows that the legal science is characterized by (a) empirical analytical, namely describing and analyzing the content and structure of law; (b) systematization of legal phenomena; (c) interpreting the substance of the applicable law, and (e) the practical meaning of legal science is closely related to its normative dimension (Herowati Poesoko, 2007: 27). Therefore, the research method is different from social research in general.

This research belongs to normative legal research (Peter Mahmud Marzuki, 2005: 29-36) namely the process of legal research carried out to produce arguments, theories, new concepts as prescriptions to answer legal issues carried out by reviewing and analyzing statutory provisions, courts decisions and other legal materials. The answer expected in legal research as a result of the analysis is right, appropriate, or wrong. Thus, the results obtained in legal research have contained value. Normative legal research is based on analysis of legal norms. In the context of normative legal research, Abdul Kadir Muhammad further argues that normative legal research is legal research that examines written law from various aspects, namely: theoretical aspects, historical aspects, philosophy, comparison, structure and composition, scope and material, consistency, general explanations and article by article, the formality and binding power of a law and the legal language used. However it does not examine the application or implementation aspects.

Regarding the objectives of the research, the methodology applies four approaches, namely the Statutory Approach, the Conceptual Approach, the Comparative Approach, and the Historical Approach. The Statutory Approach is an approach taken by examining all laws against other laws, laws and the Constitution or between regulations and laws regarding mediation, especially industrial relations mediation. The result of the study of such an approach is an argument for solving the legal issues occurs.

The Statutory Approach is used because it is possible that there may be confusion in various laws and regulations, inconsistencies and even conflicting norms between the 1945 Constitution of the Republic of Indonesia and other laws and regulations regarding the Meaning of State Control over Mineral and Coal Mining. The legislative approach applied for conducting an assessment and analysis of the consistency or conformity between the 1945 Constitution of the Republic of Indonesia, especially Article 33 paragraph (3) with Article 92 of Act No. 4 of 2009 on Mineral and Coal Mining. The Conceptual Approach is an approach carried out by examining the views and doctrines develop in the science of law originating from the opinions of experts or legislation. Thus, the ideas giving birth to legal notions, legal concepts and principles that are relevant to the legal issues occur will be found. The conceptual approach is carried out because it is possible for conceptual developments to occur regarding the principles of controlling the state. It is expected that with these four approaches, the results of the analysis will be able to answer all legal issues concerning legal consistency, legal conflicts and the principles of the State Control meaning in the minerals and coal mining sector, which will provide a contributive prescription to revise or to create new legal products. Comparative Approach is an approach carried out by making comparisons. It is carried out by comparing the concepts studied and analyzed in legal research with the concepts in the context of similar legal issues, both within the scope of the national legal system and other legal systems across countries. The Historical Approach is an approach carried out through the process of forming laws that contain or regulate legal issues that are the object of study and analysis in legal research. This historical approach is usually carried out by reviewing and analyzing the minutes of the formation of legislation governing legal issues as the object of research study.

\section{Results and Discussion}

3.1 The History of Understanding the Meaning of State Control

The value of the State Control meaning has changed from the Dutch colonial era, the Old Order era, the New Order Era to the Reformation era. As stated in Article 33 Paragraph (3) of the 1945 Constitution of the Republic of Indonesia, namely the earth and water and the natural resources contained therein are controlled by the State 
and used for the greatest prosperity of the people. This mandate is the basic law in the management of Agrarian Resources in Indonesia. The concept of The State's Right to Control is also sourced from Article 33 Paragraph (3) of the 1945 Constitution. The state is given the right /authority to control Agrarian Resources, because the earth, water and space, including the natural resources contained therein, are national assets (Article 1 Paragraph (2) of Act No. 5 of 1960, Concerning Basic Regulations). The Basic Agrarian Law (hereinafter referred to as BAL) and the State are organizations of power for all Indonesian people (Article 2 Paragraph (1) of the BAL. The authority that stems from The State's Right to Control is definitively limited by ethical obligations, which are used to achieve the greatest prosperity of the people, in the sense of nationality, welfare and independence in society and an independent, sovereign, just and prosperous Indonesian legal state (Article 2 Paragraph (3) of the BAL).

Article 33 of the 1945 Constitution is the main basis for the state's authority to control land, water and the natural resources contained therein. As a derivative, Act no. 5 of 1960 on Basic Agrarian Provisions and other legislation sectors also regulate and strengthen the State Rights to Control. In the midst of conflicts between norms and legislation in the field of natural resources, good control is needed to ensure that law sectors continue to adhere to the spirit of Article 33 of the 1945 Constitution. In this case the role of the Constitutional Court is significant to study, especially in relation to the basic considerations of the Constitutional Court in interpreting State Rights to Control; and the views and preferences of the Constitutional Court on the relationship between the state, the people and corporations in the map of land tenure and natural resources in Indonesia.

Basically, State's Rights to Control is not only considered as a normative concept regulated in Article 33 of the 1945 Constitution and the Basic Agrarian Law alone, but also as a cognitive concept that develops along with the transformation of political views and the socio-national situation of Indonesia. The circumstances behind the State's Rights to Control have mostly been contained in legal regulations. In fact the State's Rights to Control is interpreted in different contexts by each regime ruled in Indonesia.

\subsection{Definition of Meaning}

In defining a meaning, there are three approaches applied in this study, namely the conceptual, componential, and operational approaches. The conceptual approach states that every word/lexeme has inherently contained a meaning that can be in the form of ideas, concepts of things or processes. The componential approach states that each meaning of a word/lexeme consists of a number of components that make up the meaning of the word. The operational approach states that the meaning of a word/lexeme is only clear when the word/lexeme has been used in the context of a particular sentence. A meaning is also defined as a purpose of a word having different meaning. A misuse of word may become difficulties in the use of language. Thus, the word shall be properly used based on its meaning to be understandable.

\subsubsection{Lexical Meaning}

According to the Kamus Besar Bahasa Indonesia (KKBI) dan Wiktionary, "makna : arti, maksud pembicara atau penulis; pengertian yang diberikan kepada suatu bentuk kebahasaan [mean: meaning, speaker or writer's intention; the meaning given to a linguistic form]."

Menurut Wikipedia the Free Encyclopedia:

- Makna atau arti adalah hubungan antara lambang bunyi dengan acuannya [Meaning is the relationship between the sound symbol and its reference];

- Makna merupakan bentuk responsi dari stimulus yang diperoleh pemeran dalam komunikasi sesuai dengan asosiasi maupun hasil belajar yang dimiliki [Meaning is a form of response to the stimulus obtained by the actor in communication in accordance with the associations and learning outcomes they have].

Meaning is also explained as essence, limitation, definition, meaning, idea, intent, value, understanding, taste, significance, interpretation, takbir, takrif, takwil. The difference is influenced by the composition and relationship of free loose words (whole/single words that are not in the sentence) with other free words in the sentence.

\subsubsection{Opinion of Experts}

According to Purwadarminto, meaning is meaning or intent. Ullman (1972) opined that when a person thinks about the meaning of someone's words as well as the reference or vice versa, meaning will be born. Thus, meaning is a combination of meaning and words. It can be different from the exact word or is not always the same. Meaning is what is meant or what is intended (Hornby in Sudaryat,2009: 13). Dajasudarma, (1999: 5) explains that meaning is a link between the elements of the language itself. While Ferdinand de Saussure (In Abdul Chear, 1994:286) argues that meaning is a concept that is owned by a linguistic sign.

Meanwhile, Ogden and Richard (in Sudaryat, 2009: 14) defined meaning in fourteen details, namely: 1) Has an intrinsic trait, 2) Has a relationship with other objects and is difficult to analyze, 3) Other words related to words in the dictionary, 4) Connotation of words, 5) Is the essence of an activity described in an object, 6) is the place of something in the system, 7) is a practical consequence of an object in our future experience, 8) is a 
theoretical consequence of a statement, 9) an emotion that arises from something, 10) is an actual relationship and a symbol, 11) consists of a) A symbol that we interpret, b) Something we suggest, c) An event that reminds us of an appropriate event, d) An effect that petrifies certain memories when we get a stimulus, e) The use of symbols according to the actual referenced; 12) The use of symbols according to what is meant, 13) Belief in using symbols as we mean, 14) Interpretation of symbols (relationships, believing what is referred to and trusting the speaker regarding what is meant).

According to Dudung and Mulyadi the nature and meaning of values are in the form of norms, ethics, regulations, laws, customs, religious rules and other references valuable to someone. Values are abstract, are behind the facts, give rise to actions, are contained in one's morals, appear as the end of a psychological process, and develop towards more complex ones. According to Zainurrahman, there are at least two branches of discipline in linguistics that study meaning, namely semantics and pragmatics.

\subsubsection{Meaning of State Control in the Dutch Colonial Era}

Before the independence of Indonesia, the Dutch East Indies state had private property rights (domains) on land. The lands which were privately owned by the Dutch East Indies state were categorized as state lands. In the 1870s, the Dutch East Indies colonial government enacted several agrarian laws (Agrarisch Besluit) declaring state ownership of land or Domeinverklaring (Agrarisch Besluit (S.1870-118), S.1875-119a, S.1874-94f, S.188858). Agrarisch Besluit which contains Domeinverklaring was promulgated in line with the increasing opening of Dutch commercial plantation businesses, such as coffee, tobacco, tea plantations, etc, in the Dutch East Indies. With the existence of the Domeinverklaring, the Dutch East Indies state became the owner of the land that was not under private rights according to Dutch law. In other words, land for which has no evidence of rights becomes the state land, including land of indigenous peoples. Agrarisch Besluit which contains Domeinverklaring clearly violates the principle of customary law which does not have the concept of written evidence for communal ownership of customary land (Sumardjono, 2005: 60; von Benda Beckmann, 2008: 12; Burns, 1989; 38-39). However, as long as it does not conflict with billijk en rechtvaardigheid, means that propriety and justice (according to the Western version of law) are the benchmarks for whether or not customary law may apply. It means that customary law is not fully applicable, depending on whether or not it can meet these requirements.

During the Dutch East Indies era, the existence of customary law was recognized under Article 131 I.S. As a result, all customary lands fell into the property of the Dutch East Indies state so that the Dutch East Indies government could use them for their colonial interests. In the colonial era of the Dutch East Indies era, the state had ownership rights (domein) over the land.

\subsubsection{The Meaning of State Control in the Old Order Era}

The old order era was marked by the leadership of President Soekarno. The old order era had its own concept of the right to control the state. The legal basis for the Indonesian state property rights is found in Article 33 paragraphs (2) and (3) of the 1945 Constitution:

(2) Production branches which are important to the state and which affect the livelihood of the people are controlled by the state

(3) The earth and water and the natural resources contained therein shall be controlled by the state and used for the greatest prosperity of the people.

The two paragraphs of the Constitution grant the state a right called the Right to Control. The Right to Control or sometimes called The State's Right to Control is the only material right explicitly granted by the Constitution to the Indonesian state. The State's Right to Control over the earth, water, natural resources, as well as vital production branches must be used for the sake of prosperity of the Indonesian people.

The concept of State's Rights to Control actually comes from the concept of customary law which has been practiced by indigenous people long before the formation of Indonesia as a state. In customary law, public interest takes precedence over personal or individual interests. In other words, customary law is based on the concept of protecting public interests or communal interests (Kusumadara, 2000: 6). Thus objects or properties that are important for the public interest, such as water, natural resources, land, as well as science, must be jointly owned or at least jointly controlled by the community. Although customary law recognizes individual rights to objects, it still prioritizes the principle of protection public interest and the principle that a property has a social function (Kusumadara, 2000: 30).

After independence and the establishment of the Indonesian state, the Indonesian government viewed the state as the embodiment of the Indonesian people. Therefore, public or community interests were transformed into state interests. Article 33 of the 1945 Constitution was prepared based on this concept. The Indonesian People interest over the earth, air natural resources, and other branches of vital productions is transformed into the interests of the state as long as the goal is to prosper the people. Furthermore, the constitutional provisions of The State's Right to Control are applied in all Indonesian laws and regulations. 


\subsubsection{The Meaning of State Control in the New Order Era}

The New Order was marked by the leadership of the President Soeharto as the Second President of the Republic of Indonesia coming from the military. The Suharto government expanded the role of the state from only being the holder of power to being the owner of land, especially lands that did not have certificates or did not have other evidence of rights. The government called these lands the Land of the Free State (Ismail: 1994: 4) which means they can be used freely by the state, especially for development purposes. The New Order government always claimed to uphold the Constitution and the Basic Agrarian Law, but the Suharto government often issued regulations that implicitly or explicitly expanded the state's authority to own land in Indonesia. It can happen easily considering that the Suharto government has the support of the military who controls the parliament and government from the center to the regions. Below are some examples of land regulations that expand the state's authority to own land in Indonesia.

In 1967 the Suharto government promulgated Act no. 5 of 1967 on the Basic Provisions of Forestry. This Law uses the term "State Forest" for the forests located on land whose ownership rights cannot be proven or private property rights. In addition, this Law also includes customary forests belonging to customary law communities into the category of State Forests (article 2 and General Elucidation of the Basic Forestry Law). The New Order government considered communal property rights has different legal status from the private property known in the Western civil law system. So that the Government gives more legal protection to private rights, including property rights, rather than communal rights (beschikkingsrecht or customary rights) which are not known in the Western civil law system.

3.2.6 The Meaning of State Control in the Reformation Era

The Reformation Era was marked by the fall of the New Order government in 1998. In this era, the birth of the State Institution of the Constitutional Court and the Corruption Eradication Commission was also marked. Indonesia entered the era of the Reformation government, which was marked primarily by a climate of social and political freedom, reduced dominance of the central government, and the development of regional autonomy. There have been 5 (five) Presidents during the Reformation era, namely Habibie, Abdurrahman Wahid, Megawati, Susilo Bambang Yudhoyono and Joko Widodo. Although there have been many laws and regulations regarding land issued during the Reformation era, both new and amended, the government's concept of state rights to land is still similar to the concept of government before the Reformation era.

The Constitutional Court as a sign of reformation spirit tried to change this order by placing the state not as the owner of land and natural resources, but as a regulator and supervisor of land and natural resources control. The Constitutional Court viewed that State's Rights to Control was more of a public right than a private right, as well as individual and collective land rights. The Constitutional Court opined that the phrase "being controlled by the State" in the 1945 Constitution contains a higher or broader meaning than the concept of ownership in the civil law. The State Control is a public law concept related to the principle of popular sovereignty espoused in the 1945 Constitution. Sovereignty covers the fields of politics (political democracy) and economics (economic democracy). By linking the concept of state control and the sovereignty of the people, Article 33 paragraph (2) and paragraph (3) of the 1945 Constitution implicitly state that the owner of the earth, water, natural resources contained therein and the branches of production that are important and control the lives of people owned by all the people of Indonesia.

The Article 33 of the 1945 Constitution on the definition of "The State's Right to Control" or is called as "Right to Control the State" is still debatable. Actually the provisions formulated in paragraph (2) and paragraph (3) of the 1945 Constitution are exactly the same as those formulated in Article 38 paragraph (2) and paragraph (3) of the 1950 Constitution. It means that for 60 years of Indonesia's independence, there has been not uniformity on the interpretation of Article 33. The relations of the state control rights and the greatest prosperity of the people will realize the state's obligations as follows:

- All forms of utilization (earth and water) and the outcomes obtained (natural wealth) must significantly increase the prosperity and welfare of the community.

- $\quad$ Protect and guarantee all the rights of the people contained in or on the earth, water and certain natural resources that can be produced directly or enjoyed directly by the people.

- Prevent all actions from any party that will cause the people to lose the opportunity or their rights to enjoy natural resources

- The three obligations above explain all guarantees for the purpose of the state's right of control over natural resources while at the same time providing an understanding that in that right of control, the state only performs management (bestuursdaad) and processing (beheersdaad), not to do (eigensdaad).

The interpretation of the state control concept of Article 33 of the 1945 Constitution can be observed in the Constitutional Court's Decision on cases of judicial review of laws related to natural resources. The Court in its legal consideration of the Decision on the Case of the Oil and Gas Law, the Electricity Law, and the Water Resources Law interprets "the state's right to control" does not meand the state owns, but it means the state only formulates policies (beleid), makes regulations (regelendaad), arrangement (bestuursdaad), management 
(beheersdaad), and supervision (toezichthoundendaad). Thus, the meaning of State's Rights to Control for vital production branches that affect the livelihood of many people, as well as for natural resources, does not deny the possibility of individuals or the private sector to take a role, as long as the five roles of the state/government as mentioned above are still fulfilled and as long as the government and local government is not or has not been able to implement it. The interpretation of Dr. Mohammad Hatta which was later adopted by the Seminar on the Elaboration of Article 33 of the 1945 Constitution in 1977 which stated that the state business sector is to manage paragraphs (2) and (3) of Article 33 of the 1945 Constitution and in the field of financing state enterprises, it is financed by the government, if the government does not have sufficient funds to finance, the government can make internal or foreign loans, and if it is still not sufficient it can be held together with foreign capital on the basis of production sharing. One of the authorities of the Government in the management of mineral and coal mining is to determine the Mining Area after coordinating with the regional government and consult with the House of Representatives of the Republic of Indonesia [vide Article 6 paragraph (1) letter e of Law 4/2009]. Law 4/2009 has determined that Mining Area (hereinafter referred to as MA) consists of Commercial Mining Area (hereinafter referred to as CMA), People's Mining Area hereinafter referred to as PMA), and State Reserve Area (hereinafter referred to as SRA) [vide Article 13 of Law 4/2009].

According to Daud Silalahi, MA was determined based on spatial planning in which the activities shall always be based on environmental conservation efforts. It is also in accordance with Article 1 number 29 of Act no. 4 of 2009 which states, Mining Areas, hereinafter referred to as MA, is an area that has mineral and/or coal potential and is not bound by government administrative boundaries which are part of the national spatial plan. Therefore, according to the Court, the Government, in determining the MA, in addition to having to adjust to the national spatial layout and being oriented towards environmental conservation, must also ensure that the division of the three types of mining areas (CMA, PMA, and SRA) should not overlap each other, both within the same administrative area or between different administrative areas. In determining a MA, the Government must distinguish which area is a CMA, a PMA, a SRA, and the SRA will also have to be further detailed anything relate to Special Mining Business Area. This kind of management aims, in addition to avoid the emergence of overlaps on the licensing of mining activities and the designation of an area based on the national spatial plan, as well as to ensure the fulfillment of the roles and responsibilities of the state, especially the government, in order to ensure the protection, promotion, enforcement and fulfillment of economic and social rights of citizens by dividing the MA in the form of a strict and clear territorial separation into the form of CMA, PMA, and/or SRA. It is in line with Article 28I paragraph (4) of the 1945 Constitution and the United Nations Convention on Economic, Social and Cultural Rights which have been ratified by Law Number 11 of 2005 concerning Ratification of the International Covenant on Economic, Social and Cultural Rights [State Gazette of the Republic of Indonesia of 2005 Number 118, Supplement to the State Gazette of the Republic of Indonesia Number 4557]. In addition, it can also avoid the occurrence of: (1) conflicts between the actors of mining activities in the MA, (2) conflicts between the actors of mining activities and the people who are in the MA and those affected, and (3) conflicts between the mining activity actors and/or communities residing within the MA or those affected by the state, in this case the Government.

\subsection{Characteristics of Land Rights Transfer}

A characteristic is a distinguishing feature of something. It is defined as qualities or traits. It is a certain quality or feature of something. It is a distinctive or conspicuous feature of a thing. According to the KKBI, characteristic means having a special feature in accordance with a certain character. Its synonym is the word character which means inner nature that affects all thoughts, behavior and character possessed by humans or other living creatures. According to wiktionary, characteristics mean being special and being the main characteristics of someone, something etc.

3.3.1 Land Rights Transfer in the Dutch Colonial Era

The "domein verklaring" principle was used in the colonial era, which only provided benefits to the Dutch colonial government. There were Six verklaring listed in Agrarisch Besluit (Staatsblad 1870 Number 118) as implementing regulations for AgrarischWet (AW 1870). Grammatically, "Domein" means territory or land belonging to the state and "verklaring" means a statement. Thus, "Domein Verklaring" means a statement that a land whose owner cannot be proven is considered the state land. The purpose of Verklaring Domein is to control customary land for which there is no written evidence, so that it will be difficult to prove and can be controlled by the Dutch Government. The state is confident to have absolute land ownership rights. The state even revoke someone's land ownership rights whose legal existence is clearly recognized by the state. This type of spirit and view was applied by the Dutch colonial government when enacting AW 1870 in the Dutch East Indies (Indonesia).

To obtain land from the indigenous people for the benefit of investors, the Dutch colonial government used and applied a general perspective or principle set out in AW 1870 and relegated to a regulation known as Agrarische Besluit (AB). This general principle is known as Domein Verklaring. In article 1 of Agrarische 
Besluit, domein verklaring means "all land which other parties cannot prove as eigendom rights (property rights), become the domein (owned) of the State. The domein verklaring was initially applied only to the Java and Madura area and later by the colonial government was also enforced outside Java and Madura (Boedi Harsono, 2003). The in the village, whether property rights, pledges, waqaf and so on, since it is not eigendom, it belongs to the state. It also happens to erfpacht land, opstal etc., beacuse these lands are not eigendom either. The lands that are not free are called onvrij Staatsdomein. On the other hand, lands such as the peaks of Mount Merbabu and forests are vrij Staatsdomein, or raw land. Thus the state rights of the land can be lost, if the land has been renamed to eigendom rights or agrarian eigendom.

\subsubsection{Land Rights Transfer in the Old Order Era}

In the beginning of old order era, the regulation on land rights transfer was initiated by the issuance of Government Regulation Number 8 of 1953 L.N. 1953 Number 14 on Controlling State Lands, it explained that "State Lands" are lands fully controlled by the state, except if the land control along with other laws and regulations at the time the Government Regulation enforced has been submitted to the Ministry, Department or the Autonomous Region, the state land control is under the authority of the Minister of Home Affairs.

The Government Regulation Number 10 of 1961 also stated that the Head of Land Registration Office reserves the right to register a transfer of land rights anytime one of the following conditions is not fulfilled:

- The deed referred to in Article 19 is submitted without a certificate or statement as referred to in Article 25 paragraph (1) and other documents.

- Certificates and information letter regarding the condition of land rights are no longer in accordance with the existing lists at the Land Registration Office.

- If the person transferring, granting new rights, mortgaging or assigning the land rights does not have the authority to do so.

- In the selling process, exchanging, granting, granting in a will, giving according to the custom and other acts intended to transfer property rights, shall be permitted by the Minister of Agrarian Affairs or the official appointed by him.

3.3.3 Land Rights Transfer in the New Order Era

After the Independence of Indonesia, lands are generally controlled by the state as stipulated in Article 33 paragraph (3) of the 1945 constitution of the Republic of Indonesia stating that the earth, water, and natural resources contained therein are controlled by the stated and are used for the biggest prosperity of the people. Regarding the rights on land, the BAL is arranged with to provide legal certainty related to land rights held by the people. It has been clearly stipulated in Article 19 paragraph (1) of the BAL stating that: "To ensure the legal certainty by the Government, land registration is held throughout the territory of the Republic of Indonesia based on the provisions regulated by the Government Regulation." Rights on Land is the right to grant an authority to a person who has the right to cultivate or use the land.

After the enactment of the BAL, the transfer of land rights was based on Government Regulation Number 10 of 1961 on Land Registration (known as GR 10/1961) is amended by Government Regulation Number 24 of 1997 on Land Registration (GR 24/1997). In Article 37 paragraph (1) of the Government Regulation no. 24 of 1997 it is stated that, "The transfer of land rights and ownership rights to flat units through buying and selling, exchanging, grants, income in the company and other legal acts of transferring rights, except for the transfer of rights through auction can only be registered if it is proven by a deed made by the authorized Land Deed Official according to the provisions of the applicable laws and regulations. The registration of land rights is according to the provisions of Article 19 paragraph (1) of the BAL is a strong evidence of the abolition of property rights and the legality of the transfer of the land.

On the other hand, the land registration system used in Government Regulation Number 24 of 1997 on Land Registration is a negative setting which contains a positive element because it will produce letters of evidence of rights that serve as a strong evidence as stated in the BAL. The transfer of land rights according to juridical means is made in a written form with a deed drawn up by an authorized official and registered at the Regency/City land office. This step is closely related to the procedure for transferring land rights, because the procedure determines the legality of the transfer of rights. Thus, the legality of the land rights transfer is largely determined by formal and material requirements. The constitution in the formal sense is a real document as a set of legal norms that may be changed only according to special provisions, while the constitution in the material sense is the rules governing the making of general legal norms which can be in the form of a written or unwritten constitution.

\subsubsection{Land Rights Transfer in the Reformation Era}

The difference lies only in the Reformation Era. The State's Rights to Control lands is carried out the Local Government in Indonesia. It is as a result of the implementation of regional autonomy in the field of governance and finance after the Reformation Era (see Law no. 22 of 1999 replaced by the Act no. 32of 2004 on Regional Government, and Act no. 25 of 1999 replaced by Act no. 33 of 2004 on Fiscal Balance between the Central Government and the Regional Government). To increase the income of regional government, most of regional 
government in Indonesia maximized the utilization of land in the area to extract the natural resources such as minerals, mining, and palm oil. In general, the income sourced from the natural resources is used to support the political interest of the current regional government.

On the other hand, based on the State's Rights to Control land, both central and regional government issue permits or concessions for private companies to use the lands ad forests of the state. The Local Government of Indonesia generally issues mineral and coal mining permits, as well as location permits and oil palm plantation business permits to private companies, while the central government issues forest concessions and forest product collection permits.

\subsection{The Characteristic of Mineral and Coal Mining}

\subsubsection{The Nature of Mineral and Coal Mining}

Minerals and coal contained in the mining jurisdiction of Indonesia are non-renewable natural resources as a gift from God Almighty which has an important role in fulfilling the lives of many people, therefore their management must be controlled by the State to provide real added value to the national economy as an effort to achieve the prosperity and welfare of the people in a fair way. The legal principle of mining management in Law no. 4 of 2009 concerning mineral and coal mining is based on the principles of expediency, justice and balance; partiality to the interests of the nation; participatory, transparency, and accountability; sustainable and environmentally friendly. The nature of state control over mineral and coal resources in Indonesia is based on the provisions in Article 33 paragraph (3) of the 1945 Constitution, which states "Earth, water and the natural resources contained therein are controlled by the state and used for the greatest prosperity of the people." Article 33 paragraph (3) becomes the doctrine of state control and at the same time becomes the philosophical and juridical basis for managing natural resources in Indonesia.

\subsubsection{Form of Mineral and Coal Mining}

The form of mineral and coal mining management is carried out jointly by the government, regional governments and business actors. It is to show that there is no longer a monopoly on mining management by the central government. In addition, business entities and cooperatives, including individuals or local communities are also given the opportunity to conduct mining businesses in accordance with the regulated permits. Although in practice there are often obstacles, such as a long licensing bureaucracy, extortion by unscrupulous to overlapping policies between related sectors. The spirit of regional autonomy is evident in the current mining regulations. According to Article 34 of the Act no. 4 of 2009 on Mineral and Coal Mining, mining businesses is in the form of mineral and coal mining.

The Mineral mining is classified into:

- $\quad$ Radioactive mineral mining;

- Metal mineral mining

- Non-metallic mineral mining; and

- Rock mining.

However, later, there were several changes to Act Number 4 of 2009 on Mineral and Coal Mining. Law Number 3 of 2020 concerning Amendments to Act Number 4 of 2009 concerning Mineral and Coal Mining states that the Central Government in the management of Mineral and Coal Mining has 23 authorities which are the takeover of central authority distributed to the provincial and district/city governments.

Mining business actors shall prioritize contractors and local workers. The ML or SML holders are prohibited from involving their subsidiaries and/or affiliates in the mining services business in the mining business area they operate, except with the permission of the Minister, with the consideration that there are no similar mining service companies in the area; or no mining service company is interested. Mining business activities also cannot be carried out in places that are prohibited from carrying out mining business activities in accordance with the provisions of laws and regulations, unless they have obtained permission from a Government agency.

\subsubsection{Functions of Mineral and Coal Mining}

Mining management is functioned to dig natural resources wealth to obtain value added for the economy, on the other side the management of mining in which the object is non-renewable can damage the environment which will later destroy the ecosystem. While all creatures, including human, can only survive in an environment with a good and proper ecosystem. Therefore, the mining management planning shall integrates economic, environmental and socio-cultural dimensions, in order to support sustainable national development. The functions of mineral and coal management are:

- to ensure the effectiveness of the implementation and control of mining business activities in an efficient, effective and competitive manner;

- to ensure the benefits of mineral and coal mining in a sustainable and environmentally friendly manner;

- to ensure the availability of minerals and coal as raw materials and/or as a source of energy for domestic 
needs;

- to support and develop national capabilities to be able to compete at national, regional and international levels;

- to increase the income of local, regional and state communities, as well as to create job opportunities for the greatest welfare of the people; and

- to guarantee the legal certainty the implementation of mineral and coal mining business activities.

As non-renewable natural resources, mineral and coal are national wealth controlled by the state for the greatest welfare of the people. The control of minerals and coal by the state is carried out by the Government and/or local governments. For the national interest, after consulting with the House of Representatives of the Republic of Indonesia, the Government may establish a policy of prioritizing minerals and/or coal for domestic purposes. The national interest can be carried out by controlling production and exports. In the controlling process, the Government has the authority to determine the amount of production of each commodity per year for each province. The function of the mineral and coal mining law is based on the principles. Mineral and/or coal mining is managed based on the following principles:

- expediency, justice, and balance;

- partiality to the interests of the nation;

- participatory, transparency, and accountability;

- sustainable and environmentally friendly.

In granting mining permits, the government is easier to grant permits to foreign investors on due to the fact that foreign investors are more promising. The principle of accountability means that every mineral and coal mining must be accountable to the people by paying attention to a sense of justice and propriety. This principle is closely related to the rights that will be received by the government, both the central government and local governments that are sourced from mineral and coal mining activities.

3.4.4 Perspective of Certainty in Control of Mineral and Coal Mining

Article 33 of the 1945 Constitution of the Republic of Indonesia as a constitutional basis for natural resources management is translated into various laws and regulations. In this case, the translation of Article 33 of the 1945 Constitution of the Republic of Indonesia into various laws is influenced by various values and interests of the constituents which may conflict with the actual intent of Article 33 of the 1945 Constitution of the Republic of Indonesia itself. Therefore, the constitution needs to be used as a guide in producing various laws in the field of agrarian and natural resource management. Article 33 of the 1945 Constitution of the Republic of Indonesia regulates the Right to Control the State.

In this regard, the most important state control in these production branches is how the form of state control can guarantee the implementation of community welfare. Mining companies are branches of companies controlled by the state. Mineral and coal mining companies that have obtained permits are entitled to manage mineral and coal extractive. Minerals and coal are one of the strategic non-renewable natural resources controlled by the state and are vital commodities that control the livelihood of many people, and have an important role in the national economy. Therefore their management must be able to maximize the prosperity and welfare of the people. Article 33 paragraph (2) and paragraph (3) of the 1945 Constitution of the Republic of Indonesia confirms that the production branches which are important for the state and which affect the livelihood of the people are controlled by the state. Likewise, the earth, water and natural resources contained therein are controlled by the state and used as much as possible for the prosperity and welfare of the people.

To realize the management and utilization of mineral and coal mining resources for the welfare of the community, the role of the government as a regulator is practically needed in regulating exploitation in the mining sector. The role of the government is very important because the mining sector is a sector that is in demand by foreign investors. Therefore, as a state of law, in Indonesia the law must be able to guarantee legal certainty in all aspects of life, the estuary of which is to realize justice and prosperity for the lives of the Indonesian people. Justice and prosperity must be reflected in all aspects of life, meaning that all people have equal opportunities to improve their standard of living; obtain employment; obtain social services, education and health; Express opinions; exercise political rights; securing and defending the country; and to get protection and equality before the law.

Furthermore, to provide a guarantee of legal certainty, the government as a regulator through the Law on Mineral and Coal provides a legal basis to reform and restructure mining and mineral management and exploitation activities. Especially in the context of facing both national and international strategic environmental challenges and answering a number of problems in the mineral and coal mining sector due to the influence of globalization which encourages democratization, regional autonomy, human rights, the environment, development of technology and information, intellectual property rights and demands in increasing the role of the private sector and society.

In this regard, normatively legal certainty can be realized if regulations are made and promulgated with 
certainty because they regulate clearly and logically. It is clear when it does not cause multi-interpretation and logical in being a norm system with other norms so that it does not clash or cause norm conflicts. Norm conflicts arising from uncertainty of rules can be in the form of norm contestation, norm reduction or norm distortion. However, as a manifestation of the guarantee of legal certainty, basically the right to control the state according to the 1945 Constitution of the Republic of Indonesia must be seen in the context of the rights and obligations of the state as the owner of power that carries out the task of creating people's welfare. The position of the state as the governing body, the owner of that power is the embodiment of the understanding of the pattern of relations between individuals and the community in the conception of customary law whose crystallization of values are formulated in the Preamble to the 1945 Constitution of the Republic of Indonesia, so that the right to control the state means the rights and obligations that give birth to power, authority and even coercion. Thus, the definition of the right to control the state is the authority possessed by the state which contains the authority, to regulate, plan, manage and supervise the management, use and utilization of land both in the relationship between individuals, communities and the state with land as well as relationships between individuals, communities and one state and another in relation to the land.

Therefore, the rights of the community in the management of mineral and coal resources have a broad scope, it is not only the right to manage their natural resources, but also the right for the community to obtain legal protection in enjoying these rights so that their life will be guaranteed. By making the issue of community rights in mineral resource management an issue of justice, it can be claimed that the community has the right to manage natural resources or at least obtain benefits that can improve people's living standards and the State is responsible to realize it.

3.4.5 The Perspective of Justice in Mineral and Coal Mining Control

The concept of state control on mineral and coal natural resources in Indonesia is based on the provisions in Article 33 paragraph (3) of the 1945 Constitution of the Republic of Indonesia, stating that "The earth, water and natural resources contained therein are controlled by the state for the biggest prosperity of the people." Article 33 paragraph (3) becomes the doctrine of state control and the philosophical and juridical basis for the management of natural resources in Indonesia. The state also admit and respect the existence of customary law society over natural resources and their traditional rights. Article 18B paragraph (2) and Article 281 paragraph (3) of the 1945 Constitution is the constitutional basis for recognizing and protecting the rights of the indigenous people.

Both articles principally regulate legal relationship between the indigenous people and the state, and become the constitutional basis for the state administrator. Thus, the article is a declaration on:

- The state's constitutional obligation to recognize and respect indigenous peoples, and

- The constitutional rights of indigenous peoples to obtain recognition and respect for their traditional rights.

In this case, the two articles are essentially a reflection of the principle of legal justice (iustitia legalis), as stated by Thomas Aquinas, namely justice based on the law (the object is social order) which is protected by law for the common good (bonum commune). In addition, the two articles are also a reflection of the norms of distributive justice (iustitia distributive) as stated by Aristotle.

3.5 Rights of Mining License and Special Mining License Holders According to Article 92 of the Mineral and Coal Mining Law

3.5.1 The Urgency of Coal Mining and Minerals Regulation

The contribution of Mineral and Coal mining for improving people's prosperity related to the purpose of state control over national natural resources derived from the phrase "for the biggest prosperity of people". The prosperity of people from a community is identified by the economic ability in income and necessities of life. Bung Hatta stated that Independence is meaningless when the people are still suffering. The state objective is to protect the entire nation and prosper the people, as mandated in the preamble of the 1945 Constitution of the Republic of Indonesia.

On the one hand, the utilization of minerals and coal is an unavoidable positive step to meet the needs of mineral and coal commodities. This encourages efforts to exploit mineral and coal resources as much as possible. On the other hand, mining activities have an impact on the environment that is directly felt by the community around the mining area.

According to Nyoman Nurjaya, as cited by Mohamad Anis, the policy on the use of mining resources is only directed at increasing state revenues by inviting large investors. The law is centralized and is full of economic orientation. By this centralistic spirit, there is no room for regulation regarding public participation in decision-making and policy-making. The paradigm that must be developed is not only a policy on increasing state revenues, but also securing national energy, and protecting the rights of communities around mining areas. The unwise management of mineral and coal resources will cause many problems in areas that are rich in mineral and coal resources.

The emergence of conflicts between customary law community and mining companies shows that the 
positive impacts received by MHA around the mine have not been maximized, for example the blockade of mining areas, environmental problems, land compensation, cultural differences between immigrant communities and customary law communities, and other problems. Generally, the local governments have not implemented a priority scale in implementing several development sectors. Preparation of competent human resources has not been carried out. The unpreparedness of implementing regulations to support the management of mineral and coal resources also tends to be ignored, thus the above problems occur.

The main idea of Article 33 of the 1945 Constitution of the Republic of Indonesia is in line with the concept to prioritize the prosperity of the community not the individuals. It can provide prosperity in accordance with the principle of kinship in the control and or management by the state of important production branches to the state and which affect the livelihood of the people i.e., earth, water and natural resources contained therein, as well as to guarantee the state's ability to protect the public interest and the people's economic interests. With regard to mineral and coal mining, it means that every party who will carry out a mineral and coal mining project in the territory of the customary law community is obliged to provide clear information about all aspects of the mining, including the good and bad impacts on indigenous peoples. The indigenous people have the right to have sufficient time to discuss all such information and to get an understandable advice or assistance from any parties they wish using the language they understand. It is important considering the differences in value systems, ways of thinking and way of life between them and the outsiders.

The Article 18B paragraph (2) and Article 28I paragraph (3) of the 1945 Constitution of the Republic of Indonesia are the recognition and protection of natural resources in unity with the customary rights area of a customary law community. It is a consequence of the recognition of customary law as "living law" that has been going on for a long time, and has been continued until now. Therefore, the management of mineral and coal resources without the prior consent of indigenous peoples is a disregard for the rights of customary law community.

\subsubsection{Principles and Objectives of Mining and Coal Mineral Regulation}

The Article 2 of the Act Number 4 of 2009 on Mineral and Coal Mining has regulated the principles of law on mineral and coal mining. This mining shall be on the basis of:

- $\quad$ Expediency, Justice, and Balance

- $\quad$ partiality to the interests of the nation;

- $\quad$ participatory, transparency, and accountability;

- $\quad$ sustainable and environmentally friendly.

The provisions for production limitation are intended that in producing minerals, the holders of ML, SML and PML shall maintain a balance between the availability of mineral mining materials and market needs, especially the interests of the national economy. In addition, it also considers the rights and interests of future generations, because unlimited mining production means a waste and is a form of deprivation of the rights of the next generation. Such action is a form of violation of the values of justice between generations. Boedi Harsono, quoted by Urip Santoso, stated that the right of control over land contains a series of powers, obligations and/or prohibitions for the holder of the right to do something on the land being entitled. Something that is allowed, obligated and prohibited to be done which is the content of the right of control is the criteria or benchmark for distinguishing between land tenure rights regulated in land law.

3.5.3 Mineral and Coal Mining Management Authority

Based on the Act Number 4 of 2009 this authority includes the authority of central government, provincial government, and local/district government, namely:

- Determination of national policy;

- Arrangement of Legislations;

- Determination of national standard, guidelines, and criteria;

- Establishment of a national mineral and coal mining permit system;

- MA is set after coordinating with the regional government and consulting with the House of Representatives of the Republic of Indonesia;

- Granting of ML, educating, resolving conflicts, and supervising on mining businesses located across provincial areas and/or sea areas more than 12 (twelve) miles from the coastline;

- Granting ML, educating, resolving community conflicts, and supervising mines whose mining locations are in the province and/or sea area more than 12 (twelve) miles from the coastline;

- Granting of ML, educating, resolving conflicts, and supervising on mining businesses which give direct environmental impacts across provinces and/or in a sea area more than 12 (twelve) miles from the coastline;

- Granting of Exploration Mining Business License and Production Operations of Mining Business License;

- Evaluating the Production Operation ML, which is issued by the regional government, which has caused 
environmental damage and which does not apply good mining principles;

- Policies settlement on production, marketing, utilization, and conservation;

- To set out cooperation policy, partnership, and community empowerment;

- Formulation and stipulation of non-tax state revenues from mineral and coal mining business outcomes;

- Educating and supervising the management of mineral and coal mining carried out by the regional government;

- Coaching and supervising arrangement of regional regulations in mining sector;

- Investing, investigating, and researching and exploring to obtain data and information on minerals and coal as materials for the preparation of CMA and SRA;

- Management of geological information, information of potential mineral and coal resources, and national mining information;

- Guidance and supervision of post-mining land reclamation;

- Preparation of national level mineral and coal resource balances;

- Development and increase of added value of mining business activities; and

- Increasing the capacity of government officials, provincial governments, and district/city governments in the management of mining businesses.

The provincial government authority in the management of mineral and coal mining, namely:

- Making regional laws and regulations

- Granting ML, educating, resolving community conflicts and supervising mining businesses across regions, districts/cities and or sea areas from four to twelve miles

- Granting ML, fostering, resolving community conflicts and supervising mining business production businesses whose activities are located across regencies/municipalities and or sea areas from four to twelve miles

- Granting ML, fostering, resolving community conflicts and supervising mining businesses that directly impact the environment across districts/cities and or sea areas from four to twelve miles

- Inventory, investigation and research as well as exploration to obtain mineral and coal data and information in accordance with their authority

- Management of geological information, information on potential mineral and coal resources, as well as information on mining in the province/region.

- Preparation of mineral and coal resource balance in the province/region

- Development and increase in added value of mining business activities in the province

- Development and improvement of community participation in mining business with due observance of environmental sustainability;

- Coordination of licensing and supervision of the use of explosives in the mining area in accordance with their authority

- Submission of information on production results, domestic sales, and exploration to the minister and regents/mayors;

- Submission of information on production results, domestic sales, and exports to the minister and regents/mayors

- Guidance and supervision of post-mining land reclamation; and

- Increasing the capacity of provincial government officials and district/city governments in the management of mining businesses.

The authority of the district/city government in the processing of mineral and coal mining, namely:

- Making regional laws and regulations

- Granting ML and PML, educating, resolving community conflicts and supervising mining businesses in the district/city and/sea area up to 4 (four) miles.

- Granting ML and PML, guiding, resolving community conflicts and supervising production operations mining businesses whose activities are located in the district / city and / sea area up to 4 (four) miles.

- Inventory, investigation and research as well as exploration in order to obtain data and information on minerals and coal.

- Processing of geological information, information on mineral and coal potential, as well as mining formations in the district/city area

- Compilation of mineral and coal resource balance in the regency/city area

- Development and empowerment of local communities in mining businesses by taking into account environmental sustainability.

- Optimal development and improvement of added value and benefits of mining business activities

- Submission of information on the results of investment, general investigations and research, as well as 
exploration to the ministers and governors

- Submission of information on production results, domestic sales, and exports to the ministers and governors

- Guidance and supervision of post-mining land reclamation; and

- Improving the capacity of district/city government apparatus in organizing mining business processing. 3.5.4 Disharmony of Mining License and Special Mining License Holders' Right Regulations

The Article 34 of Act no. 4 of 2009 stated that mining businesses are classified into mineral mining and coal mining. Mineral mining is classified into radioactive mineral mining, metal mineral mining, non-metal mineral mining; and rock mining. The mining business is carried out in the form of: Mining License (ML), People's Mining License (PML), and Special Mining License (SML). There found a disharmony in the regulation of the rights of ML and SML holders to Article 33 Paragraph (3) of the 1945 Constitution of the Republic of Indonesia. Before further examination on which parts are synchronized between the legislation, the theoretical basis of this synchronization will be first identified. As stated in the literature review that the 1945 Constitution of the Republic of Indonesia as the legal basis, in the last few years the 1945 Constitution underwent significant changes. It does not only affect the concept and state administration system, but also penetrates into the concept of development and its implementation. Mining Business License referred to in this legal research, are actually only a few of many powers of the state in the implementation of development. The substance of the mining business license contained in Act no. 4 of 2009 concerning Mineral and Coal Mining is the implementation of the formulation of the state control concept contained in Article 33 of the 1945 Constitution of the Republic of Indonesia. As the theories opined by scholars and legal experts include:

- Kranenburg stated that a state is a group of people who establish an organization, namely the state, with the aim of maintaining the interests of the group (Soehino, 1998: 142). Basically, the power of the state is obtained from a human group or nation, the right to control the state means the right of the nation.

- According to Immanuel Kant, the state shall guarantee that every citizen is free in the legal environment. A freedom doesn't mean being able to arbitrarily do as they will. However, all actions must be in accordance with or according to what has been regulated in the law, so they must be according to the will of the people, because the law is the embodiment of the general will (Soehino, 1998: 127). This opinion is almost familiar to Rousseau's opinion that sovereignty is in the hands of the people, which is contained in the general will embodied in state legislation.

These two theory concluded that the state power on natural resources is the right of the people. The state is considered as an organization of power established by the people through community agreement which is granted authority and function to regulate and manage the potential natural resources and to perform based on the general of the people as stipulated in the Legislations. The existence of the 1945 Constitution as the legal basis reaffirms the general will of the Indonesian people in carrying out state administration. The state as the executor of the general wills of the people means that it is also acted as the representative of the people. It is emphasized in Article 1 paragraph (2), namely "Sovereignty is in the hands of the people and implemented according to the Constitution," the sovereignty of the people adopted by the Indonesian nation strengthens the position of the people as holders of the will. However, in a democratic system implies that everything is not directly controlled by the people. Thus it is called the delegation of authority from the people to the state.

\section{Conclusion}

The essence of 'State control and for the greatest prosperity of people' on mineral and coal mining is based on the principle of mineral and coal mining management, namely the principle of certainty, justice, expediency, fairness, participative, transparency, accountability, sustainability, and environmentally friendly. Besides, it shall also consider the principle of people consent on the basis of information without coercion, and also the principle of mineral and coal resources management for the sake of the people's prosperity. This principle put the people's prosperity as the development subject.

Regulation on Article 92 of Act No. 4 of 2009 on Mineral and Coal Mining which states that ML and SML holders have the right to own minerals, including associated minerals, or coal that has been produced if they have paid exploration or production royalties, except for radioactive associated minerals is contrary to Article 33 paragraph (3) of the 1945 Constitution of the Republic of Indonesia as long as the phrase 'entitled to own' in Article 92 of Act No. 4 of 2009 does not mean a civil subordinating the state.

\section{Recommendations}

Based on the above conclusions, the following recommendations are presented, namely:

- To clarify the status and meaning of the nature of being controlled by the state and for the greatest prosperity of the people on mineral and coal mining in the explanation section of the Law governing mineral and coal mining. 
- The mining regulations, especially in the case of Mining Business license, should be fixed to overcome disharmony (overlapping) among regulations so as to develop investment in the mining sector, and to manage Indonesia's natural resources for the greatest prosperity of the people.

- The rights of ML and SML holders in Article 92 of Act Number 4 of 2009 In the perspective of Article 33 paragraph 3 of the 1945 Constitution of the Republic of Indonesia is based on the interpretation of Article 33 paragraph (2) and (3) the 1945 Constitution into Act no. 4 of 2009 regarding the substance of mining business permits. To optimize the prosperity of the community, the government does not carry out mining management itself because there will be problems on funds and technology, therefore the opportunity is also given to business entities and individuals to participate in the management and exploitation, which is proven in Article 38, Article 67, Article 75 of the Act No. 4 of 2009. However, the position of the government remains as the main actor who applies the law and grants permits unilaterally by continuing to exercise the authority that is regulating (regelen), managing (besturen), and supervising (toezichthouden).

\section{References}

Admin Jurnal, (2018), "Green Marketing dan Implikasinya Terhadap Sustainable Development di Era Globalisasi, Kajian Terhadap Strategi Pemasaran yang Berkelanjutan,” Business \& Manajemen Journal, Vol. 11, No. 2.

Afiff, Suraya, at al., Redefining Agrarian Power.

Amir, Arivan, ( 2019), "Pengalihan Hak Penguasaan Tanah Menurut UUPA dalam Rangka Pendaftaran Tanah Pertama Kali," Vol. 8,.

Ardiwilaga, Roestandi, (1962), Hukum agraria Indonesia dalam teori dan praktek, Masa Baru.

Arisaputra, Muhammad Ilham, (2013), "Penerapan Prinsip-Prinsip Good Governance Dalam Penyelenggaraan Reforma Agraria Di Indonesia," Yuridika, Vol. 28, No. 2, May.

Azam, Syaiful, (2003), Eksistensi Hukum Tanah dalam mewujudkan tertib Hukum Agraria.

Bakri, Muhammad, (2011), Hak menguasai tanah oleh negara: paradigma baru untuk reforma agraria, Universitas Brawijaya Press.

Balisacan, Arsenio M., Agrarian Reform and Poverty Reduction in the Philippines.

B F Sihombing, Agrarian Reform In Indonesia: A Juridical Review.

Dwisvimiar, Inge ,(2011), “Keadilan dalam perspektif filsafat ilmu hukum,” Jurnal Dinamika Hukum, Vol. 11, No. 3.

Erwiningsih, Winahyu, Pelaksanaan Pengaturan Hak Menguasai Negara atas Tanah Menurut UUD 1945Undang-Undang Nomor 4 Tahun 2009 tentang Pertambangan Mineral dan Batubara.

Fathoni, M Yazid and Musakir Salat, Penerapan Prinsip Keadilan Dalam Pembebasan Tanah Bagi Pembangunan Untuk Kepentingan Umum.

Fitzpatrick, Daniel, (2015) "Disputes and Pluralism in Modern Indonesian Land Law," E-Jurna, Vol. 22.

Harsono, Boedi, (1986), Hukum Agraria Indonesia: Himpunan Peraturan-Peraturan Hukum Tanah, Djambatan.

Hajati, Sri, et al., 2020, Buku Ajar Politik Hukum Pertanahan, Airlangga University Press.

Hayati, Tri, (2015), Era Baru Hukum Pertambangan: Di Bawah Rezim UU No. 4 Tahun 2009, Yayasan Pustaka Obor Indonesia.

Helmi, Happy Hayati, (2019), "Reformasi Hukum Pertanahan: Pengaturan Komersialisasi Ruang Tanah," Jurnal Rechts Vinding: Media Pembinaan Hukum Nasional, Vol. 8, No. 3, December.

Hutagalung, Arie Sukanti, (2005), Tebaran Pemikiran Seputar Masalah Hukum Tanah, Lembaga Pemberdayaan Hukum Indonesia.

Ilmar, Aminuddin, (2012), Hak Menguasai Negara Dalam Privatisasi BUMN, Kencana Prenada Media Group, Jakarta.

Kaelan, (2002), Filsafat Pancasila Pandangan Hidup Bangsa Indonesia, Paradigma, Yogyakarta.

Komisi Pemberantasan Korupsi, (2018), Kajian Harmonisasi Undang-Undang Di Bidang Sumber Daya Alam Dan Lingkungan Hidup, Jakarta.

Kodir, Abdul and In'amul Mushoffa. (2017), “Islam, Agrarian Struggle, and Natural Resources: The Exertion of Front Nahdliyin for Sovereignty of Natural Resources Struggle Towards Socio-Ecological Crisis in Indonesia", KARSA: Journal of Social and Islamic Culture, Vol. 25, No. 1, June.

Kusumadara, Afifah, Perkembangan Hak Negara Atas Tanah: Hak Menguasai atau Hak Memiliki, Fakultas Hukum Brawijaya.

Marzuki, Peter Mahmud, Penelitian Hukum Edisi Revisi, Presmada Media Grup, Jakarta.

Maulidi, Muhammad Jeffry, M. Arba, dan Kaharuddin Kaharuddin, (2017), “Analisis Hukum Tentang Peralihan Hak Milik Atas Tanah Dengan Bukti Akta Di Bawah Tangan Sebagai Dasar Pendaftaran Tanah Untuk Pertama Kali (Studi Di Kabupaten Lombok Tengah)," Jurnal IUS Kajian Hukum dan Keadilan, Vol. 5, No. 3, December. 
Miharja, Meggi Okka Hadi, Andreas Dwi Setyo, and Herbowo Prasetyo Hadi, (2015 ), "Implikasi Hukum Terkait Pertambangan Rakyat Dalam Bidang MINERBA Di Indonesia," Privat Law 1, No. 7.

Nalle, Victor Imanuel Williamson, (2016), "Hak menguasai negara atas mineral dan batubara pasca berlakunya Undang-Undang Minerba," Jurnal Konstitusi, Vol. 9, No. 3.

Nurrokhman, Arsan, (2020), "Quo Vadis Indonesian Agrarian Reform: Implementation of UUPA in the President Regulation No. 86 of 2018," BHUMI: Jurnal Agraria dan Pertanahan, Vol. 5, No. 3, January.

Peluso, Nancy Lee, Suraya Afiff, dan Noer Fauzi Rachman, (2008), "Claiming the Grounds for Reform: Agrarian and Environmental Movements in Indonesia," Journal of Agrarian Change, Vol. 8, No. 2-3, April.

Putri, Rizkyana Zaffrindra and Lita Tyesta A.L.W, (2015), "Kajian Politik Hukum Tentang Perubahan Kewenangan Pemberian Izin Usaha Pertambangan Mineral Dan Batubara," Law Reform, Vol. 11, No. 2, September.

Redi, Ahmad, (2014), Hukum sumber daya alam dalam sektor kehutanan, Sinar Grafika

Sadyohutomo , M, (2018), "The benefits of an agrarian reform model in Indonesia," IOP Conference Series: Earth and Environmental Science, Vol. 202, November.

Salinding, Marthen B., (2019) "Prinsip Hukum Pertambangan Mineral dan Batubara yang Berpihak kepada Masyarakat Hukum Adat," Jurnal Konstitusi, Vol. 16, No. 1.

Santoso, Urip, (2013), Hukum Agraria, Kajian Komprehensip, Jakarta, Kencana Prenadamedia Group.

Sasmitha, Tody, et al., Pemaknaan Hak Menguasai Negara Oleh Mahkamah Konstitusi (Studyon MK Decision No. 35/PUU-X/2012; No. 50/PUUX/ 2012; and No. 3/PUU-VIII/2010) in Sekolah Tinggi Pertanahan Nasional,

Sodiki, Achmad. (2000), Politik Hukum Agraria, Konstitusi Press, Jakarta.

Suci, Ivida Dewi Amrih, Karakteristik Hukum Acara Renvoi Prosedur Dalam Perkara Kepailitan, Universitas Jember.

Thorburn, Craig, Democratizing Decentralization.

Yuking, Ana Sofa, (2013), “Kepastian Hukum dalam Undang-Undang Minerba,” Law Review, Vol. 11. 